DOI https://doi.org/10.18551/rjoas.2020-10.09

\title{
ANALYSIS OF THE INFLUENCE OF FOOD CROP PRODUCTION, DOMESTIC GROSS PRODUCTS, AND MANUFACTURER PRICES ON COST INSURANCE FREIGHT IMPORT AND FREE ON BOARD IN INDONESIA
}

\author{
Hartati Sri \\ Institiut Pemerintahan Dalam Negeri NTB, Indonesia \\ E-mail: srihartati@ipdn.ac.id
}

\begin{abstract}
This study aims to acknowledge and find empirical evidence of the effect of food crop production on gross domestic product and producer prices on cost insurance, freight, imports and free on board. The data analysis method used in this research is Partial Least Square (PLS) analysis. The results of this study indicate that the production of food crops has no positive effect on cost insurance and freight imports. Gross domestic product does not have a positive and significant effect on import freight insurance costs. Producer prices do not have a positive and significant effect on import freight insurance costs. Food crop production has a positive and significant effect on free on board. Gross domestic product has no and significant effect on free on board. The producer price has a positive and significant effect on free on board. Import cost insurance and freight does not have a positive and significant effect on free on board. Production of food crops is not significant to free on board through import freight insurance costs. Gross domestic product is not significant to free on board through import freight insurance costs. Producer prices are not significant to free on board through import freight cost insurance.
\end{abstract}

\section{KEY WORDS}

Food crop production, gross domestic product, producer prices, import cost insurance freight, free on board.

The agricultural sector has an important role in Indonesia's economic growth by directly providing food for the people, contributing to the formation of the national Gross Domestic Product (GDP), absorbing labor, generating foreign exchange, and functioning in controlling inflation. The agricultural sector in 2011, for example, contributed Rp. 313.73 trillion to the formation of national GDP where this value was greater than that in 2010 which reached Rp. 304.74 trillion. In 2011, GDP growth in the agricultural sector reached 2.95 percent compared to the previous year. The growth in the agricultural sector originated from the largest growth achieved by the fisheries sub-sector by 6.72 percent or IDR $54,064.30$ billion in 2011 , then followed by the livestock sub-sector whose role of the agricultural sector can also be seen from the ability to absorb labor. The agricultural sector workforce in 2010 and 2011 were 41.50 million and 39.33 million, respectively (CEIC2012d). The agricultural sector is the sector that is able to absorb the largest number of workers, followed by the trade and services sectors. In 2011, the agricultural sector was able to absorb 35.86 percent of the workforce which was then followed by the trade and services sector by 21.33 percent and 15.18 percent of the total workforce based on business fields. The role of the agricultural sector in the formation of foreign exchange is indicated by a positive trade balance, even though the growth rate of the trade balance fluctuates. The trade balance in the agricultural sector fluctuates due to an increase in export value followed by fluctuating developments in import value. The value of agricultural exports as a contributor to foreign exchange in 2010 was US $\$ 32,519$ million. This value increased by 41.16 percent from 2009 , while the value of agricultural imports in 2010 was US $\$ 16,874$ million. The value of agricultural imports has increased by 41.27 percent from 2009. Trade conditions in the agricultural sector indicate that the Indonesian economy is increasingly open and foreign trade activities through import and export activities are increasing. The increase in agricultural exports shows that the income of the Indonesian population is increasingly dependent on the sale of domestically 
produced goods abroad or in other words the income of the Indonesian population is increasingly dependent on the economic conditions of the importing countries. Meanwhile, the increase in agricultural imports shows that Indonesia's economy is increasingly dependent on goods produced by other countries. Thus, Indonesia's economic growth is increasingly dependent on foreign trade activities, which are related to Indonesian food production which is traded abroad.

The production of food crops is the product of the multiplication of the harvested area and productivity. Plant area data were collected monthly by the Agricultural Minister / Head of Branch Offices (KCD) using a list of cassava and corn. Food crop productivity data was collected through the Ubinan Survey by the District Statistical Coordinator (KSK) and KCD using the SUB-S List. Productivity data was collected through direct measurements on a 2.5 $\mathrm{m} \times 2.5 \mathrm{~m}$ ubinan plot at harvest time for cassava and maize.

Based on the results of the KSA survey, the harvest pattern for cassava and maize in Indonesia in the January to December 2019 period was relatively the same as the harvest pattern in 2018. The peak harvest for cassava and maize occurred in March, while the lowest harvested area occurred in December. The total harvested area for cassava and corn in 2019 was 10.68 million hectares, with the highest harvest area occurring in March, which was 1.72 million hectares. When compared with the total harvested area for cassava and maize in 2018, the harvested area for cassava and corn in 2019 has decreased by 700.05 thousand hectares (6.15 percent).

Total production of cassava and maize in Indonesia in 2019 was around 54.60 million tons of GKG, or a decrease of 4.60 million tons (7.76 percent) compared to 2018 . When compared between months, the largest decrease in production was in 2019 compared to 2018, occurred in February, which was around 2.11 million tons (Figure 1).

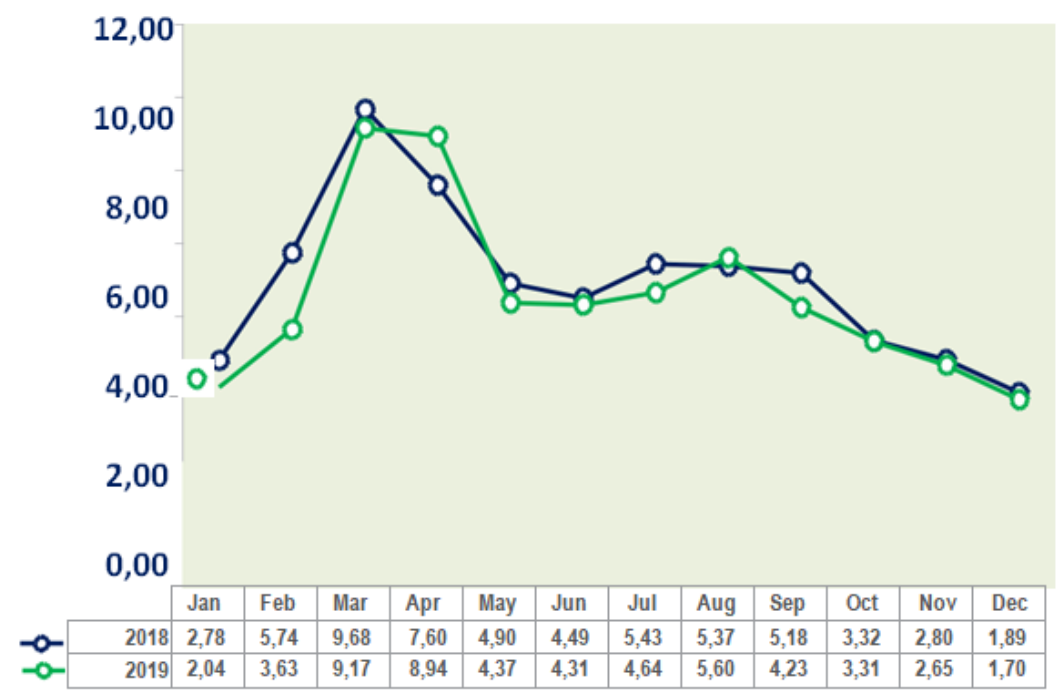

Figure 1 - Development of Paddy Production (GKG) in Indonesia, 2018-2019

Domestic production in the agricultural sector is related to the production of food crops, in fact, goods and services used both for consumption and for capital formation, do not all come from within the country but some come from abroad. On the other hand, goods and services produced domestically are not all used domestically but partly abroad, which reflects an open economy. In terms of production, it is called a Regional Product, which is the amount of added value (output - intermediate consumption) produced by production units resident in an area within a certain period (one year). In terms of income, it is called Regional Income, which is the amount of income (remuneration) received by the production factors owned by residents of an area within a certain period (one year). In terms of expenditure, it is called Regional Expenditure, namely the amount of consumption expenditure made by 
households, non-profit organizations, the government, gross fixed capital formation, changes in inventory and net exports of an area within a certain period (one year).

The productivity of a region is reflected in the domestic product, while the level of social welfare can be seen from the point of view of income after calculating the flow of income in and out of the area. PDRB is basically the amount of added value generated by all business units in a certain area, or is the sum of the value of goods and services produced in the domestic area which is then used as the "final" consumption of society, and also the welfare of farmers in terms of prices, producers obtained from buyers.

During the 2019 period, the development of the Food Crops Subsector producer prices, especially the secondary crops group, tended to increase. Meanwhile, the Horticultural Crops Subsector shows more varied price fluctuations. Price fluctuations in the Horticultural Crops Subsector were mainly seen in fruit commodities, while prices for vegetable commodities generally experienced an increase. The producer prices in the People's Plantation Subsector tend to fall, except for coconut and rubber commodities whose prices tend to rise, one of the food crops in the agricultural sector is cassava and shelled corn.
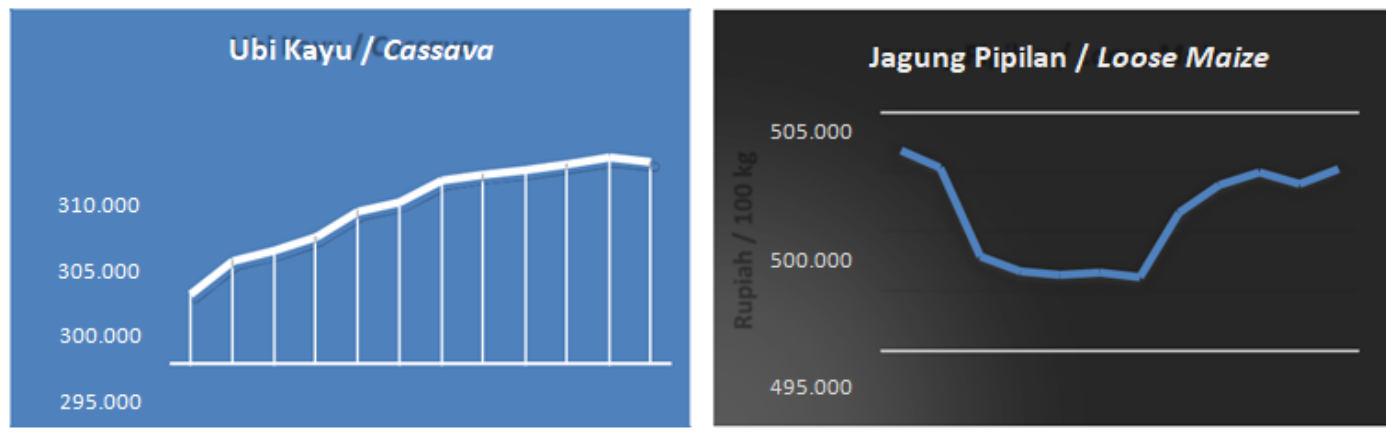

Figure 2 - Price of Cassava and Loose Maize (Rp/100 kg), 2019

Cassava as a staple food for the people in Indonesia apart from rice, the national average producer price in 2019 reached IDR 299,814 per $100 \mathrm{~kg}$. The highest average producer price occurred in November 2019 at IDR 305,809 per $100 \mathrm{~kg}$ and the lowest in January 2019 was IDR 288,677 per $100 \mathrm{~kg}$. Viewed by province, the highest average producer price for cassava occurred in Papua Province at Rp. 802,829 per $100 \mathrm{~kg}$, while the lowest was in Lampung at Rp. 161,022 per $100 \mathrm{~kg}$.

The price of shelled corn producers also increased during 2019. The average price of shelled corn producers was IDR 496,255 per $100 \mathrm{~kg}$ with the highest average price of shelled corn producers occurring in January 2019, namely IDR 501,797 per $100 \mathrm{~kg}$ and the lowest in July 2019 IDR 491,142 per $100 \mathrm{~kg}$. Viewed by province, the highest average shelled maize producer price was in Maluku Province at Rp. 713,326 per $100 \mathrm{~kg}$ and the lowest was in North Sumatra at Rp. 338,279 per $100 \mathrm{~kg}$.

\section{METHODS OF RESEARCH}

This research is an explanatory research. Explanatory research or explanatory research is research that aims to test the hypothesis which states a causal relationship between two or more variables (Sukandarrumidi, 2006: 105). This study seeks to explain the causal relationship between variables to determine whether there is a relationship between food crop production, gross domestic product, and producer prices on cost insurance freight and free on board in Indonesia.

Outer model serves to define how each indicator relates to its latent variables. The measurement model in this study was evaluated using convergent validity, discriminant validity, and composite reliability. Convergent validity relates to the principle that the gauges (manifest variable) of a construct should be highly correlated. This test is seen from the loading factor value for each construct indicator. The loading factor value range of 0.6 to 0.7 is considered sufficient (Ghozali and Latan, 2015: 74). 
Discriminant validity relates to the principle that the gauges (manifest variables) of different constructs should not be correlated with height. Discriminant Validity can be evaluated by looking at the cross loading value, namely the loading of the indicator to the measured construct is greater than loading to other constructs or by looking at the square root of Average Variance Extracted (AVE) which is greater than the correlation between constructs (Ghozali and Latan, 2015: 74).

Composite reliability value to assess constructs reliability. The composite reliability value must be greater than 0.7 , indicating that the data has a high reliability value (Ghozali 2015).

R-squares, is the coefficient of determination on endogenous constructs which is used to see the ability of exogenous variables in explaining endogenous variables. According to Chin (1998) in Ghozali and Latan (2015: 78) the R-squares value is 0.67 (good), 0.33 (moderate) and 0.19 (weak). Predictive relevance (Q square) and Effect size (f square). The effect size (f square) is calculated as the absolute value of the individual contribution of each exogenous variable to the $R$-square value of the endogenous variable. Predictive relevance ( $Q$ square) is used to measure how well the observed value is generated by the model and also its parameter estimation or to know the predictive capability with a blindfolding procedure (Ghozali 2015: 81). The value of $Q$ square> 0 indicates that the model has predictive relevance, while $Q$ square $<0$, indicates that the model lacks predictive relevance (Ghozali and Latan, 2015: 81). Furthermore, Ghozali and Latan (2015: 80) state that in relation to $f$ square, changes in $Q$ square (q square) have a relative impact on the structural model, where q square is 0.02 (weak), 0.15 (moderate) and 0,35 (strong). The inner model test is also carried out by looking at the significance value to see the effect between variables where in SEM which is more often used is the bootstrapping method (Ghozali and Latan, 2015: 80).

For the significant value of hypothesis support, a comparison of the T-table and TStatistics values can be used in the estimation results for path coefficient (path coefficient value). If T-statistics is greater than T-table, it means that the hypothesis is supported. The significant value used for the one-tailed hypothesis with a confidence level of 95 percent (alpha 5 percent) is 1.66 and the two-tailed hypothesis with a confidence level of 95 percent (alpha 5 percent) is 1.96 .

Testing the mediation effect in PLS is used to show the interaction between exogenous variables (predictors) and the mediating variables in influencing endogenous variables (Ghozali and Latan, 2015: 163). In testing the mediation effect, the output of the significance test parameter is seen in the total effect table to see the total effect of predictions (direct and indirect effect). This is because the mediation effect is not only tested for the direct effect but also the interaction relationship between exogenous variables and mediating variables on endogenous variables (indirect effect).

\section{RESULTS OF STUDY}

Evaluation of the measurement model (outer model) serves to test the validity and reliability of the model. The outer model in this study was evaluated through convergent validity and discriminant validity of the construct-forming indicators and composite reliability and Cronbach alpha for the indicator block. Convergent validity relates to the principle that the measures (manifest variables) of a construct should be highly correlated. This test is seen from the loading factor value for each construct indicator. The loading factor value range of 0.5 to 0.6 is considered sufficient. PLS Algorithm obtained the following initial results of the research model: 


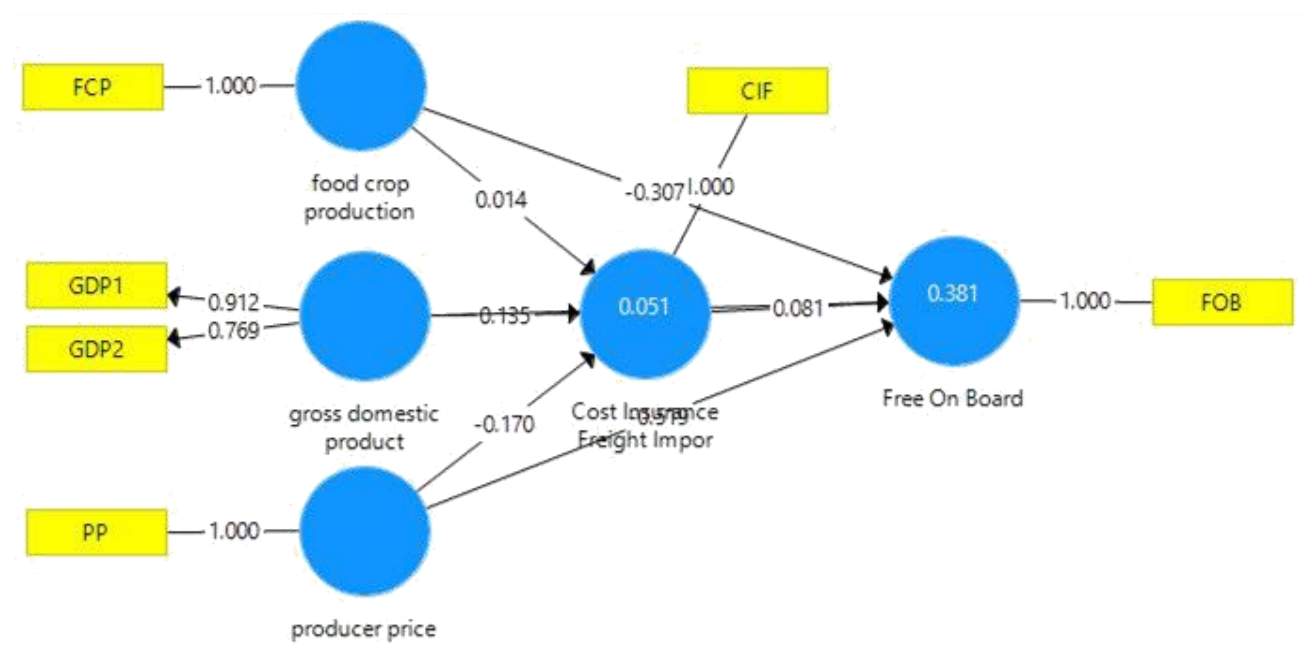

Figure 3 - Preliminary PLS Algorithm Results

The results of the analysis above show that the value of the loading factor on the GDP 1 indicator on the construct of cost insurance, freight, import and free on board, the value is greater than 0.6, namely 0.912. This means that the GDP1 indicator can measure the construct of cost insurance and freight imports free on board in this study. For, the loading factor value of the GDP2 indicator also meets the requirements of the construct validity of cost insurance and freight imports and is free on board because it has a value greater than 0.6 , namely 0.769. This indicates that the GDP1 and GDP2 indicators correlate with the constructs of cost insurance, freight, import and free on board, so this indicator is accepted from the model.

Further testing of the constructs of cost insurance, freight, import and free on board, namely through discriminant validity testing seen from the cross loading between the indicators and the constructs. If the construct correlation with the indicator is greater than the correlation of the indicator with other constructs, the construct predicts the indicators in their block better than the indicators in other blocks, so that it meets the requirements for discriminant validity (Ghozali and Hengky, 2015: 39).

Table 1 - Cross Loading

\begin{tabular}{|c|c|c|c|c|c|}
\hline $\mathrm{n} / \mathrm{n}$ & $\begin{array}{c}\text { Cost Insurance } \\
\text { Freight Import }\end{array}$ & $\begin{array}{c}\text { Food Crop } \\
\text { Production }\end{array}$ & $\begin{array}{c}\text { Free On } \\
\text { Board }\end{array}$ & $\begin{array}{c}\text { Gross Domestic } \\
\text { Product }\end{array}$ & Price Index \\
\hline CIF & 1,000 & 0,050 & 0,190 & 0,146 & $-0,182$ \\
\hline GDP2 & 0,097 & $-0,082$ & 0,155 & 0,769 & $-0,042$ \\
\hline FCP & 0,050 & 1,000 & $-0,197$ & 0,029 & $-0,191$ \\
\hline FOB & 0,190 & $-0,197$ & 1,000 & 0,246 & $-0,489$ \\
\hline GDP1 & 0,143 & 0,093 & 0,247 & 0,912 & $-0,063$ \\
\hline PP & $-0,182$ & $-0,191$ & $-0,489$ & $-0,064$ & 1,000 \\
\hline
\end{tabular}

Source: Data Processed, 2020.

Based on the table above, it is known that the cross loading between the indicators of GDP1 and GDP2 with the constructs of cost insurance, freight, import and free on board is 0.912 and 0.769 , where these values are greater than 0.70 . A cross loading value greater than 0.70 indicates that the latent construct predicts indicators in their block better than indicators in other blocks. Thus it can be concluded that the indicators of GDP1 and GDP2 have met the criteria for discriminant validity or the indicators are declared valid.

The constructs of import freight and free on board cost insurance have met the validity so that the reliability test is then carried out by looking at the composite reliability on the PLS Algorithm results. According to Ghozali and Hengky (2015: 75), the rule of thumb commonly used to assess construct reliability is that the composite reliability value must be greater than 0.70 for confirmatory research. The constructs of import freight and free on board cost 
insurance are declared reliable because they get a composite reliability value of 1,000 , this value is greater than 0.70 . Following are the results of the PLS Algorithm analysis to see the composite reliability value. Meanwhile, the construct of gross domestic product is not declared as reliability because the value is less than 0.70 .

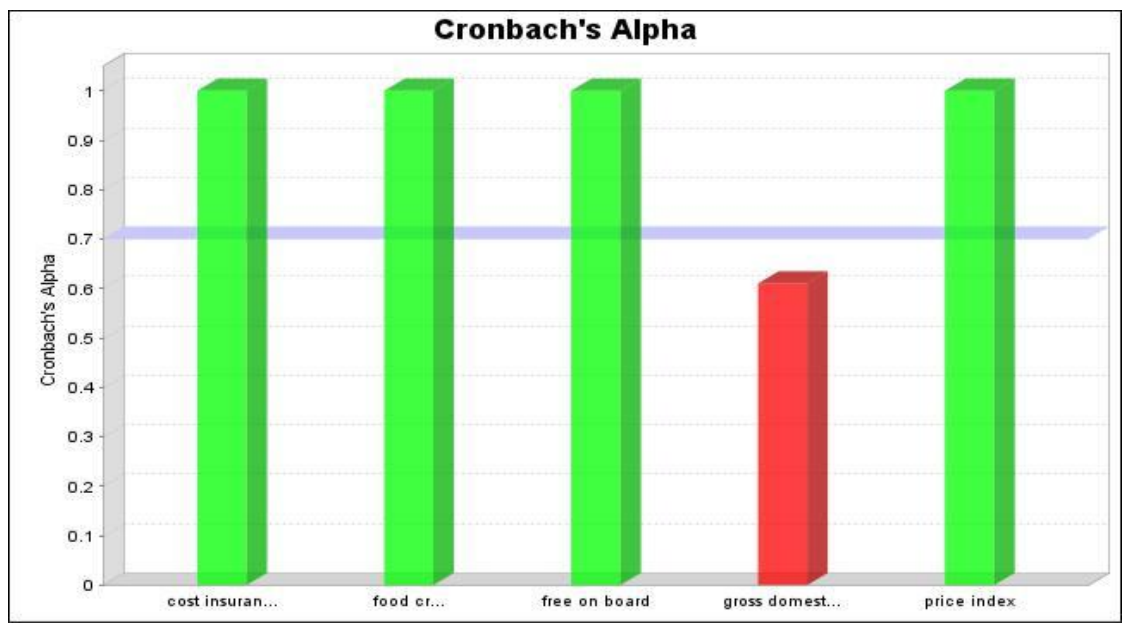

Figure 4 - Composite Reliability

The R-square value is used to explain the effect of certain exogenous constructs on endogenous constructs whether they have a substantive effect. R-square values of 0.67 , 0.33 and 0.19 can be concluded that the model is strong, moderate and weak (Ghozali and Hengky, 2015: 81). The R-square value of the analysis using the bootstrap resampling method at a significance level of 5 percent is presented in the Table.

Table 2 -R-square

\begin{tabular}{|l|l|}
\hline \multicolumn{1}{|c|}{$\mathrm{n} / \mathrm{n}$} & \multicolumn{1}{c|}{$\mathrm{R}$ Square } \\
\hline cost insurance freight import & 0,051 \\
\hline free on board & 0,381 \\
\hline
\end{tabular}

Source: Data Processed, 2020.

Based on the table above, it can be seen that the R-square value of the relationship between the variable food crop production, gross domestic product and producer prices on cost insurance and freight imports is 0.051 . The R-square value of 0.051 or 5.1 percent is classified as a weak influence model. This shows that the construct of import freight and cost insurance can be explained by the variables of food crop production, gross domestic product and producer prices by only 5.1 percent. The remaining 94.9 percent is explained by other variables outside the model built in this study, while the variable food crop production, gross domestic product and producer prices for free on board is $0.381 \mathrm{R}$-square value of 0.381 or 38.1 percent is classified as influence. moderate model. This shows that the cost free on board construct can be explained by the variables of food crop production, gross domestic product and producer prices by only 38.1 percent. The remaining 62.9 percent is explained by other variables outside the model.

Table 3 - Effect Size

\begin{tabular}{|c|c|c|}
\hline $\mathrm{n} / \mathrm{n}$ & cost insurance freight import & free on board \\
\hline cost insurance freight import & - & 0,010 \\
\hline food crop production & 0,000 & 0,146 \\
\hline free on board & - & - \\
\hline gross domestic product & 0,019 & 0,070 \\
\hline price index & 0,029 & 0,406 \\
\hline
\end{tabular}

Source: Data Processed, 2020. 
The effect size value consists of $0.02 ; 0.15$; and 0.35 . This value illustrates that the predictors of latent variables have small, medium, and large effects at the structural level. Based on the table above, it can be seen that the production of food crops, gross domestic product and producer prices each have a contribution of 0,$000 ; 0.019$; and 0.029 , which means that this variable has a weak effect on import cost insurance. For food crop production variables, gross domestic product, producer prices and cost insurance and freight imports each contributed $0.146 ; 0.070 ; 0.406$ and 0.010 , which means that these variables have a moderate effect on free on board.

The inner model test is also carried out by looking at the significance value to see the influence between variables. For a significant value of hypothesis support, a comparison of the T-table and T-Statistics values can be used in the estimation results for path coefficient (path coefficient value). If T-statistics is greater than T-table, it means that the hypothesis is supported. The significant value used for the one-tailed hypothesis with a confidence level of 95 percent (alpha 5 percent) is 1.66. In addition, to test the hypothesis, it can be done by analyzing the $p$ value compared to the errors specified in this study, namely one-tailed testing with alpha $5 \%(0.05)$. If $p$ values $<0.05$ means that the hypothesis is accepted but if $p$ values $>0.05$ means that the hypothesis is rejected. The results of the path coefficient analysis are presented in the following table.

Table 4 - Path Coefficients

\begin{tabular}{|c|c|c|c|}
\hline$n / n$ & Sample (O) & T Statistic (| O/STDEV $\mid)$ & $\mathrm{P}$ Values \\
\hline CIF $->$ FOB & 0,081 & 0,296 & 0,767 \\
\hline $\mathrm{FCP}->\mathrm{CIF}$ & 0,014 & 0,092 & 0,927 \\
\hline $\mathrm{FCP}->\mathrm{FOB}$ & $-0,307$ & 2,167 & 0,031 \\
\hline GDP $>$ CIP & 0,135 & 0,682 & 0,495 \\
\hline GDP $->$ FOB & 0,210 & 1,193 & 0,233 \\
\hline PP $->$ CIF & $-0,170$ & 0,647 & 0,518 \\
\hline$\overline{P P}->$ FOB & $-0,519$ & 2,070 & 0,039 \\
\hline
\end{tabular}

Source: Data Processed, 2020.

The first hypothesis states that food crop production has no impact on cost insurance and freight imports in Indonesia. The table above shows that the t-statistic value for the effect of food crop production on cost insurance and freight imports is 0.092 . This value is smaller than the t table value at the 5 percent significance level, namely 2.03 , so it can be concluded that the hypothesis is rejected. The $p$ value for the effect of food crop production on import cost insurance and freight is 0.927 , greater than the alpha value of 0.05 . This means that the relationship between food crop production and cost insurance and freight imports is not significant, so the hypothesis is rejected. The coefficient value of food plant production parameters against cost insurance and freight imports is 0.014 in a positive direction. This means that greater food crop production will not have an impact on import cost insurance and freight.

The second hypothesis states that gross domestic product has no impact on cost insurance and freight imports in Indonesia. The table above shows that the t-statistic value for the effect of gross domestic product on import freight insurance costs is 0.682 . This value is smaller than the t table value at the 5 percent significance level, namely 2.03 , so it can be concluded that the hypothesis is rejected. The $p$ value for the effect of gross domestic product on import cost insurance and freight is 0.492 , greater than the alpha value of 0.05 . This means that the relationship between gross domestic product and cost insurance and freight imports is not significant, so the hypothesis is rejected. The coefficient value of the gross domestic product parameter against import cost insurance and freight is 0.135 with a positive direction. This means that the greater the gross domestic product does not have an impact on import freight insurance costs.

The third hypothesis states that producer prices have no impact on cost insurance and freight imports in Indonesia. The table above shows that the t-statistic value for the effect of producer prices on cost insurance and freight imports is 0.647 . This value is smaller than the 
$\mathrm{t}$ table value at the 5 percent significance level, namely 2.03 , so it can be concluded that the hypothesis is rejected. The $p$ value for the effect of producer prices on cost insurance and freight imports by 0.518 is greater than the alpha value of 0.05 . This means that the relationship between producer prices and cost insurance and freight imports is not significant, so the hypothesis is rejected. The coefficient value of the producer price parameter against cost insurance and freight imports is -0.170 in a positive direction. This means that the higher the producer price, the lower the cost insurance and freight imports.

The fourth hypothesis states that food crop production has an impact on free on board in Indonesia. The table above shows that the t-statistic value for the effect of food crop production on free on board is 2.167. This value is greater than the table value at the 5 percent significance level, namely 2.03 , so it can be concluded that the hypothesis is accepted. The $p$ value for the effect of food crop production on free on board is 0.031 , which is smaller than the alpha value of 0.05 . This means that the relationship between food crop production and free on board is significant, so the hypothesis is accepted. The coefficient value of the food plant production parameters to free on board is -0.307 with a negative direction. This means that the greater the production of food crops, the greater the level of free on board.

The fifth hypothesis states that gross domestic product has no impact on free on board in Indonesia. The table above shows that the t-statistic value for the effect of gross domestic product on free on board is 1.193. This value is smaller than the t table value at the 5 percent significance level, namely 2.03 , so it can be concluded that the hypothesis is rejected. The $p$ value for the effect of gross domestic product on free on board is 0.233 greater than the alpha value of 0.05 . This means that the relationship between gross domestic product and free on board is not significant, so the hypothesis is rejected. The coefficient value of the gross domestic product parameter against import cost insurance and freight is 0.210 with a positive direction. This means that the greater the gross domestic product does not have an impact on free on board.

The sixth hypothesis states that producer prices have an impact on producer prices in Indonesia. The table above shows that the t-statistic value for the effect of producer prices on free on board is 2.070. This value is greater than the t table value at the 5 percent significance level, namely 2.03 , so it can be concluded that the hypothesis is accepted. The $p$ value for the effect of producer prices on free on board is 0.039 smaller than the alpha value of 0.05 . This means that the relationship between producer prices and free on board is significant, so the hypothesis is accepted. The value of the parameter coefficient of food crop production to free on board is -0.519 in a negative direction. This means that the greater the producer price, the greater the free on board rate.

The seventh hypothesis states that import freight cost insurance does not have an impact on free on board in Indonesia. The table above shows that the t-statistic value for the effect of gross domestic product on free on board is 0.296 . This value is smaller than the $t$ table value at the 5 percent significance level, namely 2.03 , so it can be concluded that the hypothesis is rejected. The $p$ value for the effect of import cost insurance and freight on free on board is 0.767 , greater than the alpha value of 0.05 . This means that the relationship between cost insurance and freight imports to free on board is not significant, so the hypothesis is rejected. The coefficient value of the cost insurance and freight import parameters to free on board is 0.210 with a positive direction. This means that the greater cost insurance and freight imports will not have an impact on free on board.

Cost insurance and freight imports are used as a mediating variable in this study. import freight cost insurance mediates the relationship between food crop production, gross domestic product, and producer prices against free on board. In the Smart PLS program analysis the mediation effect can be seen from the total effect value (Solimun, 2011).

The indirect effect of food plant production on free on board through cost insurance and freight imports has a sig value of 0.986 , greater than 0.05 , meaning that the food plant production variable is not significant to free on board through import cost insurance and freight. The indirect effect of gross domestic product on free on board through import freight cost insurance has a sig value of 0.782 , greater than 0.05 , meaning that the gross domestic 
product variable is not significant to free on board through import freight cost insurance. The indirect effect of producer prices on free on board through import freight cost insurance has a sig value of 0.936 , greater than 0.05 , meaning that the producer price variable is not significant to free on board through import freight cost insurance.

Table 5 - Indirect Effects

\begin{tabular}{|c|c|c|c|}
\hline $\mathrm{n} / \mathrm{n}$ & Sample (O) & T Statistic (| O/STDEV $\mid)$ & P Values \\
\hline FCP $>$ CIF-> FOB & 0,001 & 0,018 & 0,986 \\
\hline GDP $>$ CIP $>$ FOB & 0,011 & 0,277 & 0,782 \\
\hline PP $>$ CIP $>$ FOB & $-0,014$ & 0,080 & 0,936 \\
\hline
\end{tabular}

Source: Data Processed, 2020.

\section{DISCUSSION OF RESULTS}

This study aims to analyze and provide empirical evidence regarding the effect of food crop production, gross domestic product, and producer prices on cost insurance, freight, imports and free on board in Indonesia, as well as analyzing and providing empirical evidence of the effect of food crop production, gross domestic product, and producer prices on free on board through cost insurance and freight imports in Indonesia. Previously, a descriptive analysis had been carried out on the research variables and PLS analysis to examine the relationship or influence between the constructs in the study.

The hypothesis states that food crop production has no impact on cost insurance and freight imports in Indonesia. The results showed that the t-statistic value for the effect of food crop production on import cost insurance and freight was 0.092 . This value is smaller than the t table value at the 5 percent significance level, namely 2.03, so it can be concluded that the hypothesis is rejected. The $p$ value for the effect of food crop production on import cost insurance and freight is 0.927 , greater than the alpha value of 0.05 . This means that the relationship between food crop production and cost insurance and freight imports is not significant, so the hypothesis is rejected. The coefficient value of food plant production parameters against cost insurance and freight imports is 0.014 in a positive direction. This means that the greater the production of food crops, the less cost insurance and freight imports will be. The results of the study explain that the community or farmers do not feel disadvantaged by the import of food crop production because the level of public consumption is actually higher and they are interested in imported food. This also resulted in the economic growth of Indonesian farmers not too high because the price set by the Indonesian government itself was the same as the price of food from outside. And this is not in accordance with the costs incurred by farmers in producing food. This policy problem has triggered the conversion of land use by agriculture to industrial land. As a result, agricultural land has become less and less narrow, and the supply of food security for Indonesia is decreasing.

The hypothesis states that gross domestic product has no impact on cost insurance and freight imports in Indonesia. The results showed that the t-statistic value for the effect of gross domestic product on cost insurance and freight imports was 0.682 . This value is smaller than the t table value at the 5 percent significance level, namely 2.03 , so it can be concluded that the hypothesis is rejected. The $p$ value for the effect of gross domestic product on import cost insurance and freight is 0.492 , greater than the alpha value of 0.05 . This means that the relationship between gross domestic product and cost insurance and freight imports is not significant, so the hypothesis is rejected. The coefficient value of the gross domestic product parameter against import cost insurance and freight is 0.135 with a positive direction. This means that the greater the gross domestic product does not have an impact on import freight insurance costs. The total market value of all final goods and services produced in the agricultural sector in the domestic economy during a given period. As an alternative, we can also define GDP as total expenditure or total income in the economy that does not affect cost insurance and freight imports because the Indonesian population still lacks production of goods in the agricultural sector. 
The hypothesis states that producer prices have no impact on cost insurance and freight imports in Indonesia. The results showed that the t-statistic value for the effect of producer prices on cost insurance and freight imports was 0.647 . This value is smaller than the t table value at the 5 percent significance level, namely 2.03 , so it can be concluded that the hypothesis is rejected. The $p$ value for the effect of producer prices on import cost insurance and freight is 0.518 greater than the alpha value of 0.05 . This means that the relationship between producer prices and cost insurance and freight imports is not significant, so the hypothesis is rejected. The coefficient value of the producer price parameter against cost insurance and freight imports is -0.170 in a positive direction. This means that the higher the producer price does not have an impact on import freight insurance costs. The development of food crop prices has no effect on cost insurance and freight imports, therefore the development of food crop prices can be used as a partial indicator of the development of the welfare of the community and farmers. Price is one of the determinants of the success of a producer because it determines how much profit a producer will get from selling its products in the form of goods and services. The increase in agricultural commodity prices was mainly influenced by several factors. These factors are weather, food production, and pests and diseases. Of the four factors, the dominant factor affecting agricultural commodity prices is food production.

The hypothesis states that food crop production has an impact on free on board in Indonesia. The results showed that the t-statistic value for the effect of food crop production on free on board was 2.167. This value is greater than the table value at the 5 percent significance level, namely 2.03 , so it can be concluded that the hypothesis is accepted. The $p$ value for the effect of food crop production on free on board is 0.031 which is smaller than the alpha value of 0.05 . This means that the relationship between food crop production and free on board is significant, so the hypothesis is accepted. The coefficient value of the food plant production parameters to free on board is -0.307 with a negative direction. This means that the greater the production of food crops, the greater the level of free on board. The results show that the higher the export of food crops will reduce the productivity of food in Indonesia. Higher imports reduce productivity because it will affect domestic food prices. The price of imported food production is clearly lower than the price of domestic food. The impact is on reducing production by farmers, because farmers are less enthusiastic about planting food crops if the selling price is low. Farmers will look for other alternative commodities that are attempted to obtain better profits. The exchange rate affects export and import assets, because it is related to commodity prices at the domestic and world levels. A stronger exchange rate will cause exports to increase due to higher domestic prices. Likewise, if the opposite happens, namely the exchange rate weakens; imports will increase because world prices of goods will decline.

The hypothesis states that gross domestic product has no impact on free on board in Indonesia. The results showed that the t-statistic value for the effect of gross domestic product on free on board was 1.193. This value is smaller than the table value at the 5 percent significance level, namely 2.03 , so it can be concluded that the hypothesis is rejected. The $p$ value for the effect of gross domestic product on free on board is 0.233 greater than the alpha value of 0.05 . This means that the relationship between gross domestic product and free on board is not significant, so the hypothesis is rejected. The coefficient value of the gross domestic product parameter against import cost insurance and freight is 0.210 with a positive direction. This means that the greater the gross domestic product does not have an impact on free on board.

The sixth hypothesis states that producer prices have an impact on free on board in Indonesia. The results showed that the t-statistic value for the effect of producer prices on free on board was 2.070. This value is greater than the t table value at the 5 percent significance level, namely 2.03 , so it can be concluded that the hypothesis is accepted. The $p$ value for the effect of producer prices on free on board is 0.039 smaller than the alpha value of 0.05 . This means that the relationship between producer prices and free on board is significant, so the hypothesis is accepted. The value of the parameter coefficient of food crop production to free on board is -0.519 in a negative direction. This means that the greater the 
producer price, the greater the free on board rate. The impact of the effect of producer prices on free on board was a decline in production and exports, while imports increased. However, the growth response is relatively small compared to the baseline data, so that it does not interfere with national food availability. For food crop commodities, the impact of rising producer prices is relatively the same, namely an increase in production and exports, while imports decline, increase in producer prices, has a positive impact on food security. To maintain food security, synergistic policies between central and regional governments need to be implemented, improving agricultural infrastructure, markets and institutions (credit, extension), so that food production and exports increase.

The hypothesis states that import cost insurance and freight does not have an impact on free on board in Indonesia. The results showed that the t-statistic value for the effect of gross domestic product on free on board was 0.296 . This value is smaller than the table value at the 5 percent significance level, namely 2.03, so it can be concluded that the hypothesis is rejected. The $p$ value for the effect of import cost insurance and freight on free on board is 0.767 , greater than the alpha value of 0.05 . This means that the relationship between cost insurance and freight imports to free on board is not significant, so the hypothesis is rejected. The coefficient value of the cost insurance and freight import parameters to free on board is 0.210 with a positive direction. This means that the greater cost insurance and freight imports will not have an impact on free on board. This research is in line with the theory of international trade, if the number of goods or services that are exported abroad is increasing, the domestic product must also produce more goods and services. An increase in imported goods will increase production goods imported from abroad so that domestic productivity will decrease further which will reduce domestic economic growth.

The indirect effect of food plant production on free on board through cost insurance and freight imports has a sig value of 0.986, greater than 0.05, meaning that the food plant production variable is not significant to free on board through import cost insurance and freight. The indirect effect of gross domestic product on free on board through import freight cost insurance has a sig value of 0.782 , greater than 0.05 , meaning that the gross domestic product variable is not significant to free on board through import freight cost insurance. The indirect effect of producer prices on free on board through import freight cost insurance has a sig value of 0.936 , greater than 0.05 , meaning that the producer price variable is not significant to free on board through import freight cost insurance.

\section{CONCLUSION}

The production of food plants does not have a positive effect on cost insurance and freight imports. This means that the greater the production of food crops, the less cost insurance and freight imports will be. Gross domestic product does not have a positive and significant effect on import freight insurance costs, the greater the gross domestic product does not have an impact on import freight cost insurance. Producer prices do not have a positive and significant effect on import freight insurance costs, the greater the producer prices, the lower the import freight insurance costs. Food crop production has a positive and significant effect on free on board, the greater the production of food crops the greater the level of free on board. Gross domestic product has no and significant effect on free on board, the greater the gross domestic product does not have an impact on free on board. The producer price has a positive and significant effect on free on board, the greater the producer prices the greater the free on board level. Import freight cost insurance does not have a positive and significant effect on free on board, the greater the import freight cost insurance does not have an impact on free on board. the food crop production variable is not significant to the free on board through import freight insurance costs. Gross domestic product is not significant to free on board through import freight insurance costs. Producer prices are not significant to free on board through import freight cost insurance. 


\section{REFERENCES}

1. Badan Pusat Statistic Indonesia 2019. Gross Regional Domestic Product Of Provinces In Indonesia By Expenditure.

2. Badan Pusat Statistic Indonesia 2019. Production of Food Crops.

3. Badan Pusat Statistic Indonesia 2019 Statistik Harga.

4. Ghozali, Imam dan Hengky Latan. 2015. Partial Least Square: Konsep, Teknik dan Aplikasi Menggunakan Program SmartPLS 3.0. Semarang: Badan Penerbit Universitas Diponegoro.

5. Hartono, Jogiyanto. 2014. Metode Penelitian Bisnis, Salah Kaprah dan Pengalamanpengalaman. Edisi Keenam. Yogyakarta: BPFE.

6. Indriantoro, Nur dan Bambang Supomo. 2014. Metode Penelitian Bisnis Untuk Akuntansi \& Manajemen. Cetakan Keenam. Yogyakarta:BPFE.

7. Isdijoso B. 1992. Model Ekonomi Makro dan Keterkaitan Sektor Pertanian Di Indonesia [Tesis]. Bogor (ID): Institut Pertanian Bogor.

8. Kuznets S. 1971. Economic Growth of Nations. Cambridge (AS): Harvard University Press. Laoh, I. O. E. H., Olfie, I. B. L. S., \& Dumais, I. J. N. K (2013). Pengaruh Produksi Tanaman Pangan Terhadap Indeks Harga Pangan Di Kota Manado. Cocos, 3(5).

9. Marina, S., Darmawati, A., \& Setiawan, I (2014). Pengaruh Kualitas Pelayanan terhadap Loyalitas Pelanggan pada Perusahaan Penerbangan Full Service Airlines. Jurnal Manajemen Transportasi \& Logistik (JMTransLog), 01(02), 157-164. Retrieved from http://u.lipi.go.id/1422409785\%0Ahttp://ejournal.stmttrisakti.ac.id/index.php/JMTRANSL OG/article/view/15\%0Ahttp://issn.pdii.lipi.go.id/issn.cgi?daftar\&1394520852\&1\&\&

10. Pahlavani M. 2005. Cointegration and Structural Change In The Exports - GDP Nexus: The Case of Iran. International Journal of Applied Econometrics and Quantitative Studies. Vol. 2(4): 1-20.

11. Purwono Nugroho Pengaruh Standar Keamanan Pangan Terhadap Ekspor Produk Biofarmaka Indonesia Ekonomi, J., \& Pembanguan, K (2014). Jurnal Ekonomi dan Kebijakan Pembanguan, hlm. 58-81 Vol 6 No 1, 6(1), 47-60.

12. Rizki Syarif Pratama 2015 Analisis Pengaruh Luas Panen, Harga Ekspor Dan Produksi Pangan Nabati Terhadap Jumlah Ekspor Pangan Nabati Jawa Tengah. Jobs (Jurnal of Business Studies).

13. Utomo, S (2012). Dampak Impor Dan Ekspor Jagung Terhadap Produktivitas Jagung Di Indonesia. Etikonomi, 11(2), 158-179. https://doi.org/10.15408/etk.v11i2.1891

14. Waheed M. 2007. Structural Breaks and Unit Root: Evidence from Pakistani Macroeconomic Time Series. MPRA Paper. Vol 1797(07): 1-20.

15. Will M and Guenther D. 2007. Food Quality and Safety Standards as required by EU Law and the Private Industry. A Practitioners Reference Book. Agriculture, Fisheries and Food. Division 45.

16. Wilson JS dan Otsuki T. 2004. To spray or not to spray: pesticides, banan exports, and Food Safety. Food Policy 29(2): 131-146. 